\title{
TEKNOLOGI MULTI MEDIA FILTER UNTUK MEMPRODUKSI AIR BERSIH DI LAHAN GAMBUT
}

\author{
MULTI MEDIA FILTER TECHNOLOGY FOR PRODUCING \\ CLEAN WATER ON PEATLANDS AREA \\ ${ }^{1)}$ Emi Roslinda, ${ }^{2}$ Gusti Hardiansyah \\ ${ }^{1,2)}$ Fakultas Kehutanan Universitas Tanjungpura \\ J1. Imam Bonjol Pontianak 78124 \\ email: eroslinda71@gmail.com
}

\begin{abstract}
ABSTRAK
Ketersediaan air bersih adalah permasalahan yang masih terus dihadapi oleh masyarakat di kota Pontianak terutama mereka yang tinggal di kawasan bergambut. Sumber air bersih yang diandalkan adalah dari air hujan, yang menjadi sangat terbatas ketersediaannya ketika terjadi musim kemarau. Kegiatan PKM ini bertujuan untuk memperkenalkan dan melatih masyarakat untuk memproduksi air bersih di lahan gambut dengan menggunakan teknologi multi media filter (MMF). Teknologi MMF yaitu teknik penyaringan air gambut menggunakan dua tahap penyaringan dengan dua tabung. Adapun bahan penyaring yang digunakan adalah antrasit, pasir, kerikil, ijuk, arang(karbon). Sasaran utama adalah masyarakat di Kelurahan Batu Layang RT05/RW13 dan RT05/RW14 yang air gambutnya sudah tercemar akibat limbah peternakan babi dan Tempat Pembuangan Akhir sampah Kotamadya Pontianak. Metode yang diterapkan adalah difusi ipteks, sosialisasi, pembangunan instalasi air dan partisipasi aktif masyarakat, sehingga terbangun dua unit instalasi air untuk memproduksi air bersih di lahan gambut. Adanya kegiatan PKM ini masyarakat sudah memperoleh pengetahuan untuk memproduksi air bersih yang diharapkan dapat membantu mengatasi permasalahan ketersediaan air bersih.
\end{abstract}

Kata kunci : Air Bersih, Gambut, Multi Media Filte

\section{ABSTRACT}

The availability of clean water is a problem that is still being faced by people in the city of Pontianak, especially those who live in peat areas. The source of clean water is from rainwater, which becomes very limited when the dry season occurs. This PKM activity aims to introduce and train people to produce clean water on peatland area using multi-media filter (MMF) technology. MMF technology is a peat water filtration technique using two filtering stages with two tubes. The filter material used is anthracite, sand, gravel, palm fiber, charcoal (carbon). The main target is the community in Batu Layang RT05 / RW13 and RT05 / RW14 Village whose peat water has been polluted due to the waste of pig farms and the Final Waste Disposal Site of Pontianak Municipality. The methods applied are science and technology diffusion, socialization, construction of water installations and active community participation, so that two water installation units were built to produce clean water on peatlands. The existence of this PKM activity is the community has gained knowledge and skill to produce clean water which is expected to help the problem of the availability of clean water.

Keywords: Clean Water, Multi Media Filter, Peat 


\section{PENDAHULUAN}

Kelurahan Air Tawar Barat meru Permasalahan air bersih adalah hal rutin bagi masyarakat di Kalimantan Barat. Sumber air lain yang diandalkan masyarakat Kalimantan Barat untuk di konsumsi adalah air hujan. Ketersediaan air hujan menjadi terbatas pada musim kemarau, apalagi pada musim kemarau tersebut banyak masyarakat yang melakukan pembakaran untuk membersihkan lahan dan membuka lahan baru, sehingga asap dan debu hasil pembakaran akan mencemari udara. Apabila hari hujan, airnya tidak dapat ditampung karena kotor tercemar debu sisa pembakaran dan warna air hujan hitam dan kotor. Cara lain untuk mendapatkan air layak konsumsi adalah membeli air kemasan. Tetapi cara ini hanya dapat dilakukan oleh masyarakat kota ekonomi menengah keatas, untuk masyarakat yang rata-rata mata pencahariannya petani cara ini sulit dilakukan.

Lahan di Kawasan Kelurahan Batu Layang adalah kelurahan yang sebagian besar terdiri dari lahan gambut. Lahan gambut adalah salah satu sumberdaya lahan yang mempunyai fungsi hidrologis, sangat potensial menyimpan air berupa air gambut. Menurut Kusnaedi (2006) air gambut adalah air permukaan yang mempunyai ciri-ciri berwarna merah kecoklatan, $\mathrm{pH}$ rendah, kandungan zat organik yang tinggi, kekeruhan dan kandungan partikel tersuspensi dan kandungan kation yang rendah, warna cokelat kemerahan pada air gambut merupakan akibat dari tingginya kandungan zat organik terlarut terutama dalam bentuk asam humus dan turunannya. Akibat kondisi ini kebutuhan akan air bersih dan jernih dan layak konsumsi sulit untuk dipenuhi di kawasan ini. Air gambut tergolong air yang tidak memenuhi persyaratan air bersih yang telah ditetapkan oleh Peraturan Menteri Kesehatan RI No. 492/MENKES/PER/IV/2010 tanggal 19 April 2010, beberapa karakteristik yang tidak memenuhi persyaratan adalah sebagai berikut:

1. Segi estetika yaitu dengan adanya warna, kekeruhan dan bau pada air gambut akan mengurangi efektifitas usaha desinfeksi, karena mikroba terlindung oleh zat padat tersuspensi, baik yang bersifat anorganik maupun yang organik. Hal ini tentu berbahaya bagi kesehatan bila terdapat mikroba yang pathogen.

2. $\mathrm{pH}$ rendah pada air gambut menyebabkan air terasa asam yang dapat menimbulkan kerusakan gigi dan sakit perut (Notodarmojo, 1994)

3. Kandungan zat organik yang tinggi dapat menjadi sumber makanan bagi mikroorganisme dalam air yang dapat menimbulkan bau apabila zat organik tersebut terurai secara biologis dan jika dilakukan desinfeksi dengan larutan khlor akan membentuk senyawa organokhlorine yang bersifat karsinogenik (Notodarmojo, 1994).

4. Tingginya kadar besi $(\mathrm{Fe})$ pada air merupakan suatu hal yang harus diperhatikan dalam penyediaan air bersih bagi masyarakat, karena selain mengurangi segi estetika, juga mengurangi efektifitas usaha desinfeksi karena mikroba terlindung oleh zat tersuspensi. Tingginya kadar besi pada air menyebabkan air berwarna merah kecoklatan dan berbau logam sehingga menimbulkan keengganan untuk mengkonsumsinya (Sutrisno, 2006).

5. Endapan mangan (Mn) akan memberikan noda-noda pada bahan/benda-benda yang berwarna putih. Adanya unsur ini dapat menimbulkan baud an rasa pada minuman (Sutrisno, 2006).

Berdasarkan hasil penelitian A'idah et all (2018) tentang karakteristik air gambut di Kota Pontianak dan Kabupaten Kubu Raya diperoleh air gambut memiliki pH sekitar 4 sampai 5,7, 
konduktivitas sekitar $1,31 \mu \mathrm{S} / \mathrm{cm}$ sampai $82,2 \mu \mathrm{S} / \mathrm{cm}$, kekeruhan $1,31 \mu \mathrm{S} / \mathrm{cm}$ sampai $82,2 \mu \mathrm{S} / \mathrm{cm}$, dan semua air gambut berwarna cokelat, kandungan zat organik sekitar $11 \mathrm{mg} / \mathrm{L}$ sampai $16 \mathrm{mg} / \mathrm{L}$, kesadahan total $590 \mathrm{mg} / \mathrm{L}-1302 \mathrm{mg} / \mathrm{L}$, kadar $\mathrm{Fe} \quad 2 \mathrm{mg} / \mathrm{L} \quad-\quad 5 \quad \mathrm{mg} / \mathrm{L}$. Jika dibandingkan dengan penelitian Suhendar et all (2012) mengenai air gambut di dusun Pulo Gambut Desa Suka Rame Baru Kecamatan Kuala Hulu Kabupaten Labuhan Batu Utara terdapat beberapa perbedaan yang menunjukkan karakteristik gambut berbeda-beda di setiap lokasi. Pada penelitian Suhenda et all (2012) $\mathrm{pH}$ air gambut: 4,5-4,8, kandungan $\mathrm{Fe} 0,9 \mathrm{mg} / \mathrm{L}$, Mn 0,17 mg/L dan BOD 15,73 - 16,27 $\mathrm{mg} / \mathrm{L}$. Dari kedua penelitian ini melebihi standar yang ditetapkan. Ini mengindikasikan bahwa air gambut tanpa pengolahan memang tidak layak untuk dikonsumsi.

Untuk lokasi Kelurahan Batu Layang, kondisi ini diperparah oleh keadaan di hulu sungai yang ditemukan peternakan babi dan lokasi kawasan Tempat Pembuangan Sampah Akhir (TPA). Di daerah seperti ini air tanahnya adalah air tanah dangkal berupa air gambut yang tercemar limbah peternakan babi dan lindi sampah dari TPA. Jika dipakai untuk mencuci pakaian berwarna dapat menyebabkan warna pakaian berubah menjadi kuning ke coklatan dan berbau. Jika digunakan untuk konsumsi beresiko untuk kesehatan. Oleh karena itu penting dilakukan pengolahan air yang dapat menghasilkan air bersih yang layak dikonsumsi.

Permasalahan yang dihadapi mitra untuk saat ini adalah kurangnya sumber air bersih ataupun cadangan air bersih untuk pemenuhan kebutuhan rumah tangga. Masyarakat di sekitar kawasan Kelurahan Batu Layang di kecamatan Pontianak Utara hanya mengandalkan air hujan yang ditampung di tong-tong penampungan, sehingga apabila tiba musim kemarau masyarakat kehabisan persediaan air hujan sehingga yang digunakan adalah memanfaatkan air gambut yang mengalir di sungai, parit dan air kolam. Sebagian air hujan yang jatuh akan tertampung sebagai air tanah dan sebagian yang lain akan mengalir sebagai aliran permukaan yang masuk kedalam parit-parit dalam bentuk air gambut yang telah tercemar oleh limbah aktifitas peternakan babi dan lindi sampah dari Tempat Pembuangan Sampah Akhir (TPA) yang berada di hulu sungai. Hal ini di buktikan selain airnya berbau tidak sedap juga ditunjukkan oleh warna air yang coklat dan keruh.

Salah satu teknologi yang dapat menghasilkan air bersih adalah dengan menggunakan teknologi multi media filter (MMF). MMF ini akan mampu mengatasi air gambut yang tercemar menjadi air yang siap konsumsi karena air telah disaring/filter dengan beberapa tahapan sehingga dihasilkan air yang berkualitas, TDS rendah, bebas warna, bebas bau, bebas rasa serta masalah air bersih menjadi teratasi. Penggunaan teknologi MMF ini selain diperoleh air yang jernih dan bebas bau dan rasa juga akan berakibat pada peningkatan kesehatan masyarakat melalui penyediaan air bersih.

Prinsip dasar dari teknologi MMF adalah filtrasi. Filtrasi adalah suatu proses pemisahan zat padat dari fluida (cair maupun gas) yang membawanya menggunakan suatu medium berpori atau bahan berpori lain untuk menghilangkan sebanyak mungkin zat padat halus yang tersuspensi dan koloid. Selain dapat mereduksi kandungan zat padat, filtrasi dapat pula mereduksi kandungan bakteri, menghilangkan zat warna, rasa, bau, besi dan mangan. Ini tergantung pada media yang dilewati oleh fluida yang difiltrasi. Proses filtrasi biasanya dari hasil koagulasi(klarifier) atau setelah melewati primary filter untuk menghilangkan suspended solid yang terbentuk pada proses koagulasi. Setelahnya akan melewati media penyaring. Jenis media penyaring bermacam-macam tergantung 
kandungan apa yang akan dihilangkan untuk proses filtrasi. Bisa menggunakan satu jenis media atau dua jenis media. Jika lebih dari satu jenis media, maka dinakan multi media filter.

Tujuan kegiatan ini adalah untuk memperkenalkan dan melatih masyarakat untuk memproduksi air bersih di lahan gambut dengan menggunakan teknologi multi media filter (MMF), sehingga masyarakat diharapkan dapat memprduksi air bersih secara mandiri.

\section{METODE}

Pelaksanaan kegiatan melibatkan partisipasi aktif masyarakat sasaran, dalam hal ini adalah kelompok petani lele Tani Bunda yang merupakan masyarakat RT05/RW13 dan kelompok petani lele Sejahter di RT05/RW14 kelurahan Batu Layang yang ketersediaan air bersih mereka sangat terbatas karena air parit yang biasa digunakan saat ini tercemar limbah peternakan babi dan limbah TPA sampah kota. Sumber air bersih hanya mengandalkan sumur bor yang airnya pun berwarna coklat dan air hujan yang ketersediannya sangat terbatas. Karena ketersediaan air yang terbatas maka kelompok tani lele tersebut akhirnya terhenti.

Metode kegiatan yang digunakan adalah dengan difusi ipteks dan sosialisasi. Selain itu kegiatan ini juga dilaksanakan menggunakan metode partisipatif, yaitu metode kegiatan yang melibatkan peran aktif masyarakat sasaran di setiap tahapan kegiatan (Wibowo, 2009). Kegiatan ini dilakukan untuk memproduksi air bersih yang layak konsumsi, meliputi kegiatan pembangunan instalasi air bersih, sosialisasi, penyuluhan dan demonstrasi.

Adapun sketsa pembuatan alat penyaring air gambut multi media filter (MMF) dapat di lihat pada Gambar 1 .

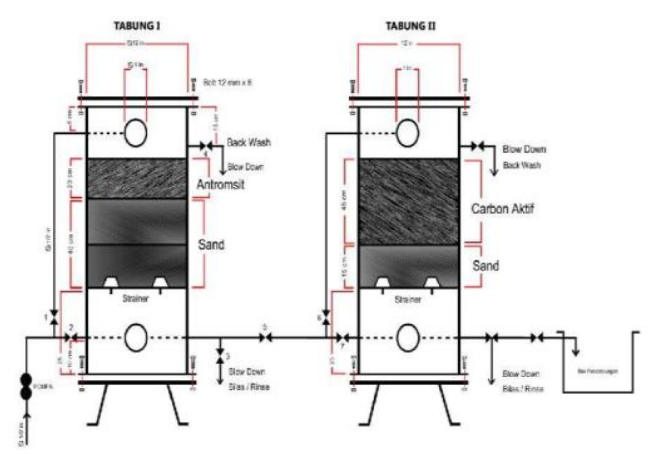

Gambar 1. Sketsa Instalasi MMF (PT. SBK/HJT, 2010)

\section{Adapun prosedur kerja operasional MMF}

1. Proses produksi air bersih (tahap i pada tabung i)

Air dari sumber air gambut di sedot dengan menggunakan pomba sanyo masuk ke dalam tabung selinder I melalui bagian lubang atas tabung. Air disaring oleh antrasit yang berfungsi menyaring flok/kotoran dari air dan selanjutnya di saring kembali oleh lapisan ke dua melalui sand filter (pasir), disaring lagi oleh lapisan ketiga batu kerikil, disaring lagi oleh lapisan keempat ijuk, dan terakhir partikel yang halus di saring kembali oleh strainer.

\section{Penyaring Tahap II pada Tabung II}

Air dari hasil penyaring pada tahap I dari Tabung I di alirkan pada Tabung II. Dalam Tabung II terjadi proses penyaringan oleh carbon filter (arang) yang langsung berfungsi untuk menghilangkan bau, warna dan rasa. Kemudian air melalui sand filter (pasir) dan ijuk dan saringan terakhir strainer di lapisan bawahnya, jadi air di saring secara bertingkat. Air bersih siap di alirkan pada bak penampungan.

3. Proses Pencucian Balik (Back Wash) pada Alat Pembersih Air

Air di alirkan dari lubang bagian bawah tabung, stop kran menuju lubang bagian atas di tutup. Stop kran back blow 
down dibuka. Air ditendangkan dari bawah ke atas sehingga kotoran dan flok/lumpur ke luar bersama air yang keluar dari lubang back wash. Pencucian di nyatakan selesai jika air yang keluar sudah kelihatan bersih dan jernih. Air jernih membuktikan bahwa kotoran yang ada pada batu kerikil, pasir/sand filter, ijuk dan pada arang/karbon aktif dan antrasit sudah habis terbuang.

\section{Proses Pembilasan (Rinse)}

Stop kran dari Tabung I bagi bagian bawah kembali di tutup. Stop kran menuju lubang bagian atas di buka, air dimasukkan dari lubang bagian atas Tabung I. Stop kran back wash down di tutup. Stop kran rinse dibuka, air bilasan keluar dari Tabung I melalui antrasit, pasir (sand filter), batu kerikil dan ijuk serta strainner turun menuju stop kran rinse dan kondisi air bilasan di kontrol sampai keadaan bersih. Pembilasan dinyatakan selesai.

\section{HASIL DAN PEMBAHASAN}

Pelaksanaan kegiatan PKM di Kelurahan Batu Layang telah berhasil membangun 2 unit instalasi multi media filter untuk menghasilkan air bersih. Peletakan instalasi ditetapkan berdasarkan kesepakatan dengan ketua RW 13 dan RW 14 bersama warganya. Peletakan instalasi diletakkan di RW 13 di rumah ketua RW 13, sementara di RW 14 diletakkan di rumah ketua RW 14. Setiap unit instalasi mempunyai bak tampungan. Dengan kapasitas tanki penampungan sebanyak 2000 liter (2 kubik) maka sekali pengolahan air bersih masyarakat dapat memproduksi air sebanyak 2000 liter. Gambar 2 menunjukkan instalasi air yang dibagun:

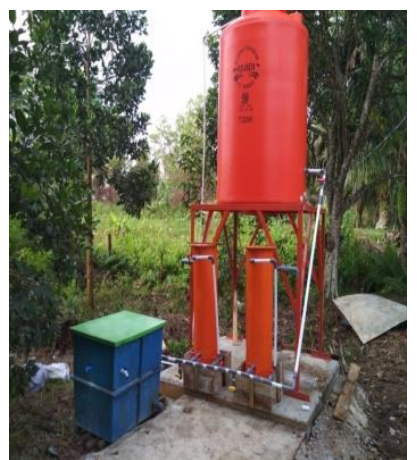

Gambar 2: Instalasi air dengan teknologi MMF

Kegiatan pembangunan instalasi air dan sosialisasi PKM mendapatkan respon yang sangat baik dari masyarakat sasaran. Hal ini dikarenakan rasa ingin tahu yang tinggi untuk dapat memproduksi air bersih di lokasi di mana masyarakat tinggal yang sumber airnya hanya dari sumur bor saja, karena air parit sudah tercemar limbah peternakan babi dan pembuangan sampah. Selain itu kegiatan dilakukan saat musim kemarau sedang berlangsung sehingga kebutuhan akan air bersih sangat terasa. Difusi ilmu pengetahuan dan teknologi diawali dengan pembuatan instalasi air, praktek penggunaan alat instalasi, praktek penjernihan air dan juga cara memelihara instalasi air yang sudah dibangun. Cara pemeliharaan sangat penting untuk disampaikan karena merupakan salah satu hal yang perlu diperhatikan dalam penggunaan media filter. Karena setelah digunakan dalam kurun waktu tertentu, filter akan mengalami penyumbatan akibat tertahannya partikel halus dan koloid.

Masyarakat sangat antusias dalam proses pembuatan instalasi, karena merupakan hal yang baru dan memang dibutuhkan untuk pemenuhan kebutuhan air. Air parit yang sudah tercemar menyebabkan sumber air semakin sedikit. Air parit tidak bisa lagi dipakai untuk kegiatan penduduk seperti mandi dan mencuci karena telah menimbulkan keluhan kesehatan kulit di masyarakat, hal ini dikarenakan bahwa penggunaan air sungai yang tercemar untuk keperluan 
MCK dapat menyebabkan keluhan seperti gatal-gatal dan kulit bersisik (Suhendra, et all. 2012). Kegiatan pembuatan instalasi yang terdiri dari dua tabung penyaringan dan berbagai keran untuk penjernihan dan pembilasan memang memerlukan perhatian serius sehingga masyarakat paham untuk membuatnya secara swadaya.

Setelah mengikuti demonstrasi dan pembuatan instalasi, kegiatan selanjutnya adalah proses penjernihan air gambut yang berasal dari sumur bor masyarakat. Bahanbahan yang digunakan adalah antrasit, pasir, batu kerikil dan ijuk. Pasir berfungsi untuk membersihkan kotoran, sementara antrasit digunakan untuk menghilangkan bau dan rasa yang disebabkan oleh senyawa-senyawa organik. Antrasit adalah karbon yang timbul melalui proses metamorfosa dari tumbuhan dengan waktu yang lama, bermula dari kayu - lumut batubara - (lignit) - batubara - antrasit. Selain itu juga digunakan PAC untuk mengikat zat-zat tersuspensi dan terlarut sehingga menyebabkan air menjadi jernih. Terdapat prosedur yang sederhana yang bisa dilakukan oleh masyarakat secara swadaya dalam menghilangkan warna dan zat organik dalam air gambut yaitu setiap $1000 \mathrm{ml}$ air gambut diperlukan penambahan 0,10 gram kaporit, 0,05 gram kapur tohor, 0,30 gram tanah lempung dan 0,40 gram tawas (Suherman dan Sumawijaya, 2013; Widiastuti dan Latifah, 2017). Setiap penambahan zat, dilakukan pengadukan secara manual dengan batang pengaduk selama 30 detik, kemudian dibiarkan dalam waktu 5 menit, akan terbentuk larutan yang bening dan endapan berwarna cokelat. Namun prosedur yang dilakukan pada kegiatan ini sedikit berbeda, dikarenakan kandungan zat organik dan senyawanya berbeda. Pada kegiatan ini penjernihan dilakukan dengan menggunakan Costic dan PAC untuk menghasilkan air yang jernih dan $\mathrm{pH}$ air diatas 7 sehingga bisa dikonsumsi. Pada kedua tempat komposisi penambahan Costic dan PAC jumlahnya juga berbeda.
Untuk instalasi pengolahan air di RW 13 cara pemakaian bahan penjernih air adalah sebagai berikut:

1. Pastikan air dalam tong mencapai takaran 2000 liter (2 kubik)

2. Encerkan masing-masing 3,6 ons Costic dan 2,8 ons PAC dalam wadah yang berbeda

3. Ukur $\mathrm{pH}$ (keasaman) air di dalam tong, jika kurang dari 7 maka naikkan $\mathrm{pH}$ menjadi 7 dengan memasukkan Costic yang sudah diencerkan dan diaduk hingga merata

4. Jika $\mathrm{pH}$ sudah mencapai 7 , masukkan larutan PAC dan aduk hingga merata

5. Tunggu proses pengendapan/endapkan selama kurang lebih satu jam (lebih lama) maka air yang dihasilkan akan lebih jernih

6. Air dapat digunakan

\section{Catatan :}

Jika pengisisan air merupakan pengulangan, maka Costic dapat dikurangi setengahnya.

Sementara untuk yang di RW 14, penambahan Costic dan PAC lebih banyak jumlahnya yaitu masing-masing adalah: untuk Costic 8,8 ons dan PAC 8,0 ons. Hal ini dikarenakan air di RW 14 tingkat tercemarnya lebih tinggi. Sementara prosedur yang lain sama.

Berikut gambar hasil penjernihan air gambut yang dilakukan :

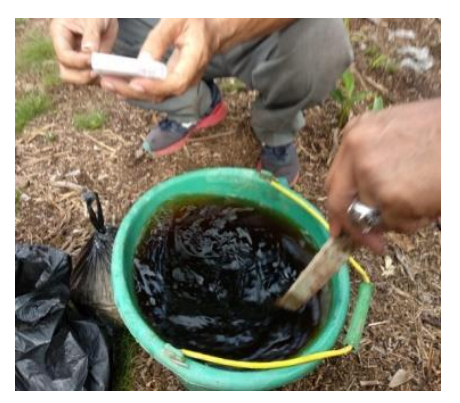

Gambar 3: Hasil penjernihan air 
Dari gambar 3 tampak hasil penjernihan air yang dilakukan terjadi perubahan terutama dari warna dan bau yang signifikan dari air sumur bor sebelum dan setelah penjernihan. Selain itu $\mathrm{pH}$ air yang dihasilkan sudah meningkat sampai 7 , dimana sebelumnya air gambut mempunyai $\mathrm{pH}$ berkisar antara 3-6.

Dari gambar 4 yang tersaji di atas setelah seluruh rangkaian instalasi terpasang tampak bahwa terdapat penambahan alat multi media filter. Hal ini dikarenakan dengan satu tahapan multi media filter saja tidak mampu membuat air gambut di lokasi PKM menjadi jernih, masih terdapat warna kecoklatan yang berasal dari air gambut yang diolah. Oleh karena itu tim PKM melakukan penyaringan tahap dua dengan menggunakan multi media filter lagi, sehingga alat pengolahan air yang diserahkan ke masyarakat adalah berupa dua multi media filter yang disebut dengan double multi media filter atau double MMF. Ini merupakan terobosan baru yang membedakan alat pengolahan air gambut dari yang sudah ada sebelumnya. Adapun hasil air yang diperoleh dari proses pengolahan dengan double multi media filter dapat dilihat dari gambar berikut:

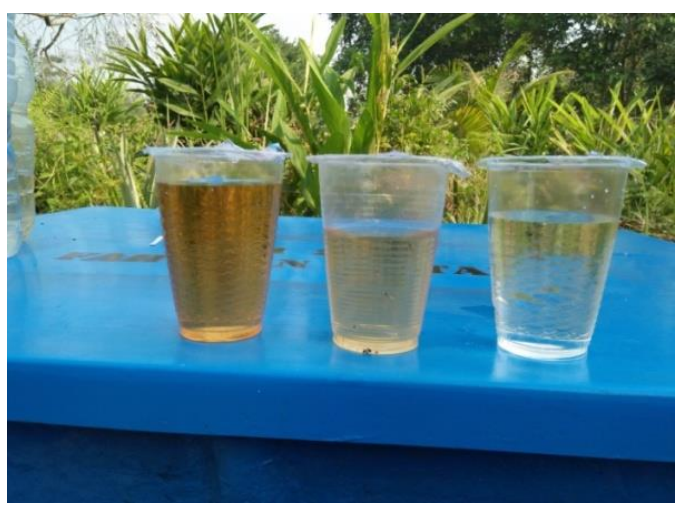

Gambar 4: Hasil pengolahan air gambut dengan double multi media filter

Penggunaan double multi media filter dalam mengolah air gambut telah berhasil meningkatkan kebasaan air gambut yang awalnya memiliki $\mathrm{pH} 5$ menjadi 8,4 dan 8,5, yang sudah di uji laboratorium di Dinas Kesehatan Propinsi Kalimantan Barat dengan metode SNI 066989.11-2004 dan warna air yang jernih. Walaupun sudah mencapai kebasaan yang cukup tinggi, untuk keperluan konsumsi sebagai air minum tetap disarankan untuk dimasak terlebih dahulu.

\section{SIMPULAN}

Kegiatan PKM Teknologi MMF di kawasan gambut telah menghasilkan 2 unit instalasi multi media filter untuk menghasilkan air bersih di dua lokasi mitra yaitu di RT 05/RW 13 dan RT 05/RW14 Kelurahan Batu Layang Kecamatan Pontianak Utara Kotamadya Pontianak. Kegiatan ini telah meningkatkan pengetahuan dan wawasan masyarakat untuk memperoleh air bersih dari sumber air gambut secara mandiri guna memenuhi kebutuhan air bersih yang selama ini berwarna keruh dan tercemar limbah peternakan dan pembuangan sampah. Tingkat partisipasi yang tinggi dari mitra program memberikan dampak positif bagi pelaksanaan program, terlihat dari keberhasilan masyarakat melakukan kegiatan pengolahan air secara mandiri.

\section{DAFTAR PUSTAKA}

A'idah E, Destiarti L, Idiawati N., (2018). Penentuan karakteristik air gambut di Kota Pontianak dan Kabupaten Kubu Raya. Jurnal Kimia Khatulistiwa 7(3): 91-96.

Departemen Pekerjaan Umum, (1980). Pengolahan Air Gambut Individual untuk daerah Rawa Pasang Surut (Bergambut). Pusat Penelitian dan Pengembangan Pemukiman Badan Penelitian dan Pengembangan, Jl.Pattimura no. 
20, Kebayoran Baru, Jakarta Selatan.

Departemen Pekerjaan Umum, Direktorat Jendral Cipta Karya. Penunjuk Praktis Pembangunan Pengolahan Air Gambut. http://www.google.com 23 Desember 2012.

Kusnaedi, (2006), Mengolah Air Gambut dan Air Kotor Untuk Air Minum, Bogor: Penebar Swadaya

Notoadmojo S., (1994). Air Berwarna, Kajian terhadap Studi Laboratorium. Palangkaraya: Makalah, Lokakarya Pengolahan Air Berwarna.

Peraturan Menteri Kesehatan Republik Indonesia No. 492/Menkes/Per/IV/2010. (2010). Tentang Persyaratan Kualitas Air Minum

PT. SBK/HJT, (2010). Penjernihan Air (Water Purification). Jakarta: Alas Kusuma Group.

Pusat Informasi Wanita, (1991). Buku Panduan Air dan Sanitasi. Pusat Informasi Wanita dalam Pembangunan PDII-LIPI bekerja sama dengan Swiss Development Coorperation, Jakarta.

Suhendar, DP., Marsaulina I., Nuraini DS. (2012). Analisa Kualitas Air Gambut dan Keluhan Kesehatan Pada Masyarakat di Desa Suka Rame Baru Kec. Kuala Hulu Kab. Labuhan Batu Utara. Medan: Departemen Kesehatan Lingkungan Fakultas Kesehatan Masyarakat Universitas Sumatera Utara.

Sutrisno T., Suciastuti E., (2006). Teknologi Penyediaan Air Bersih. Jakarta: Rineka Cipta.
Wibowo, A.H., (2009). Analisis Perencanaan Partisipatif: Studi kasus di Kecamatan Pemalang Kabupaten Pemalang, Thesis. Semarang: Program Pasca Sarjana Universitas Dipenogoro.

Widiastuti, T., dan Latifah, S., (2017). Pemberdayaan petani lahan gambut melalui proses penjernihan air gambut. Jurnal Pengabdian dan Pemberdayaan Masyarakat 1(2):155-159. 